\title{
Research Models Used in Doctoral Theses on Sport Management in Turkey: A Content Analysis
}

\author{
Ahmet Atalay \\ School of Physical Education and Sport, Ardahan University, Turkey
}

Copyright $\bigcirc 2018$ by authors, all rights reserved. Authors agree that this article remains permanently open access under the terms of the Creative Commons Attribution License 4.0 International License

\begin{abstract}
The aim of this study was to examine the methodological tendencies in the doctorate theses which were prepared in the field of Sports Management in Turkish between 2007 and 2016 and which were open to access in the database of the Council of Higher Education (CHE) National Theses Center. In this context, 111 doctorate theses prepared in the last decade were examined. The study was conducted with the Qualitative Research Method, which is frequently used in social sciences, and the Case Study Method was also made use of in the course of the study. The data obtained in the study were analyzed and interpreted with the Content Analysis Method. According to findings, it was determined that the study method was not mentioned in 92 of the 111 doctorate theses, which were included in the study; the study design was not mentioned in 36 of them; and the sampling method was not mentioned in 46 of them. It was also determined that the Questionnaire Method was used frequently in the doctorate theses that were examined in the context of the study; and the Data analysis methods that were used frequently were the Descriptive and Predictive Analysis Methods. As a result, it is possible to claim that the methodological structures of the doctorate theses are extremely missing and inadequate. In addition, it is clear that the methodological structures of the theses are weak and unclear, and cannot convey the methodological data to the reader in an accurate manner. Right at this point, it may be recommended to consider the doctorate thesis literature on Sports Management again, and certain and meticulous rules are set for future studies in terms of writing styles and methodological structures.
\end{abstract}

Keywords Sport Management, Doctorate Thesis, Content Analysis, Methodology, Research Trends

\section{Introduction}

The history of Sports Education dates back nearly to one hundred years. As a matter of fact, the first steps for Sports
Education were taken in 1926 by Selim Sırrı Tarcan with the opening of Physical Education course in Istanbul Çapa [1]. Then, in 1932, "Gazi Secondary School Teachers and Training Institute" was established and the name of this institution was changed in 1947 as Gazi Educational Institutions, Physical Education Department. Gazi Educational Institution was followed by Educational Institutions Physical Education Departments in Istanbul, Izmir and Diyarbakır [2].

After the institutional structuring in Sports education, "Sports Academies" were established in 1974 under the umbrella term of "Academy" in Ankara, Istanbul and Manisa, respectively. In 1977, Physical Education and Sports High School (PESHS) started education in Ege University for the first time [3]. As of 1980, it is possible to claim that many developments were observed both in Turkey and in the whole world, and many institutions were affected by these developments. One of these institutions was the educational ones in those years. Especially with the globalization, many steps were taken in Turkey for the purpose of re-structuring education. Karakaya and Çoban [4] stated in his study that higher education institutions contributed greatly to the development of culture and values in the society in globalizing world. In this context, the Council of Higher Education (CHE, "YÖK" in Turkish) was established in 1982, which may be considered as the milestone of higher education in Turkey. With this council, a new structuring that was specific for sports was started.

With the Higher Education Law that was enacted in 1982, all the institutions in the field of physical education and sports were collected under the department of Physical Education and Sports; and Physical Education and Sports High Schools were opened under the jurisdiction of university rectors with a regulation made in 1992 [3]. Today, according to the statistical data of $\mathrm{CHE}$, it is determined that education is provided on sports in 58 Physical Education and Sports High School (PESHS) at undergraduate level; in 31 Sports Sciences Faculty (SSF) and in 3 Sports Sciences and Technology High School (SSATHS) [5]. This academic structuring has been visualized in Figure 1 below. 


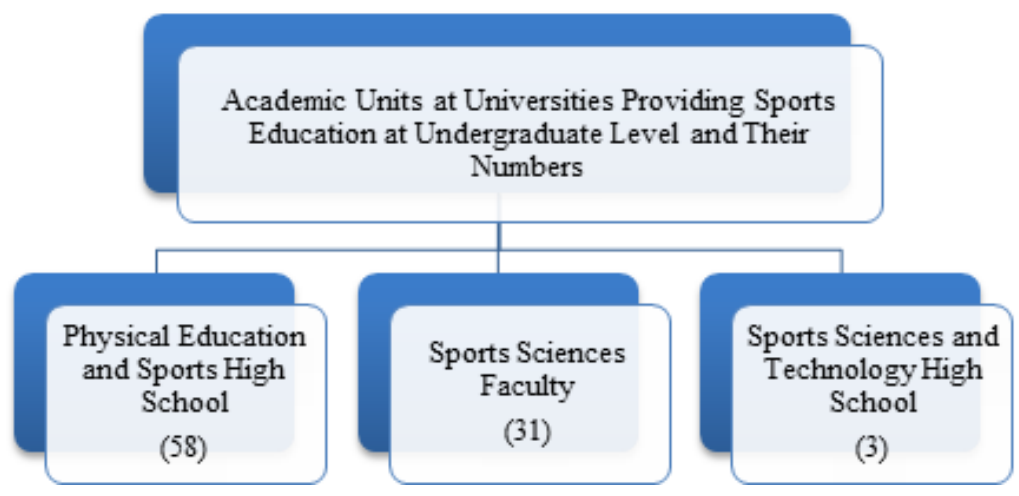

Figure 1. Academic Units Providing Sports Education at Undergraduate Level at Universities and Their Numbers

When Figure 1 is analyzed, it is seen that the academic units at universities providing sports education at undergraduate level are PESHS, SSF, and SSATHSO. It is also clear in the figure that the academic unit with the highest number is the Physical Education and Sports High School (PESHS).

Specifically in Sports Sciences, Physical Education and Sports High School (PESHS), SSF, and SSATHSO continue to provide education in the field of Physical Education teaching, Physical Education and Sports Sciences, Movement and Training Unit, Sports Management, Recreation, Physical Education and Sports for the Handicapped, Exercise and Sports Sciences for the Handicapped Departments [5]. These academic units and departments are visualized in Figure 2 below.

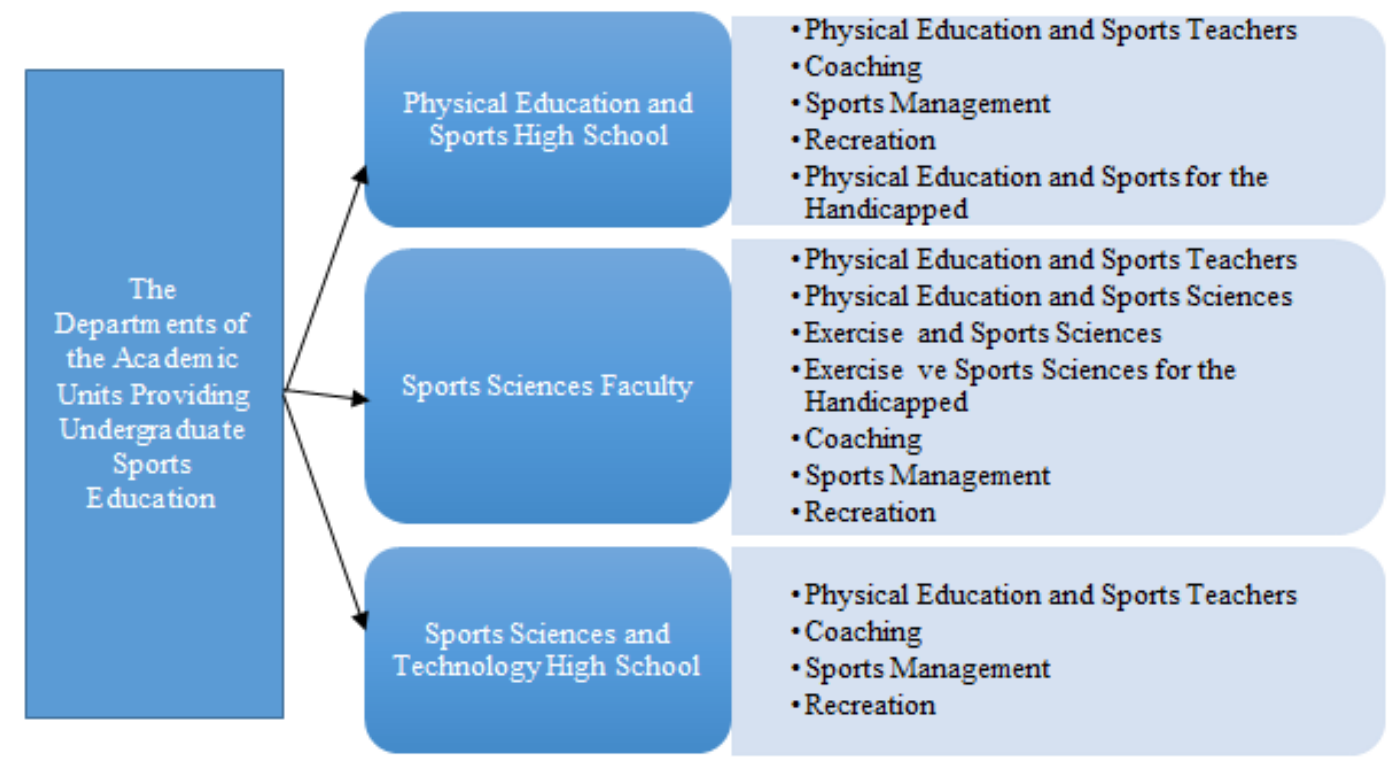

Figure 2. The Departments of the Academic Units Providing Sports Education at Undergraduate Level

When the Departments of the Faculty and High Schools providing sports education are analyzed, it is clearly seen that the departments both at the faculty level and at high school level are the same, and the Physical Education and Sports Teachers, Training, Sports Management and Recreation Departments are all included. Different from these departments, there are Physical Education and Sports Sciences, Exercise and Sports Sciences and the Handicapped Exercise and Sports Sciences Departments in Sports Sciences Faculty.

Sport management it is also the name given to many university-level academic programs that prapare students to assume position in the spor industry [6]. As mentioned by Chalip (2006), sport management should be a distinctive discipline with a sports-focused model, which requires expertise and advanced research in sport management disciplines [7]. Managing sport organizations at the start of the twenty-first century involves the application of techniques and strategies evident in the majority of modern business, government and nonprofit organizations. So, students seeking a career as a sport manager need to develop an understanding of the special features of sport and its allied industries [8]. Depending on these developments sport management programs have significantly increased in many universities, most likely due to the interest of students, academics, and employers [9]. Sports management department emerged as one of the sub-disciplines of Management Sciences under the Physical Education and Sports High Schools (PESHS) in early 2000s, and has become a department that aims to train 
qualified sports managers and sports scientists with undergraduate and postgraduate education levels.

The qualitative and quantitative competencies of the academicians are extremely definitive in the formation of scientific infrastructure in Sports Sciences departments for the purpose of providing education at academic level. Since the establishment of Gazi Educational Institute, it is possible to claim that the academicians in the field of Sports Sciences have contributed to the spread of sports as a scientific branch. As of today, the number of the academicians working at Physical Education and Sports High School (PESHS), SSF and SSATHSOs of universities in Turkey is 1671 [5]. The numerical data on the titles, personal cadres and genders of these academicians are visualized in Table 1 below.

Table 1. The Number of the Academicians in the Units of the Universities Providing Education

\begin{tabular}{|c|c|c|c|}
\hline \multirow{2}{*}{ Title } & \multicolumn{2}{|c|}{ Gender } & \multirow{2}{*}{ Total } \\
\cline { 2 - 3 } & Male & Female & \\
\hline Professor Doctor & 70 & 15 & 85 \\
\hline Assoc. Prof. & 185 & 43 & 228 \\
\hline Assist. Prof. & 414 & 153 & 567 \\
\hline Teaching Assistant & 289 & 89 & 378 \\
\hline Lecturer & 43 & 22 & 65 \\
\hline Specialist & 12 & 4 & 16 \\
\hline Research Assistant & 248 & 84 & 332 \\
\hline Total & 1261 & 410 & 1671 \\
\hline
\end{tabular}

In Table 1, numerical data on the academic staff employed in the units of the universities providing Sports Education are given. According to these data, it is seen clearly that the academic staff are the most in Assist. Prof. status (567). Then, Teaching Assistants (378), and Research Assistant are the third (332).
It is not possible to expect that only undergraduate education is adequate in order to raise qualified individuals, and to acquire scientists in this country and society. It is extremely important that individuals continue post-graduate degree education after undergraduate level and receive master's degree and doctorate education, and have a scientific viewpoint. As a matter of fact, it is crucial that countries gain a scientific insight and raise their own scientific doctors. When considered in this aspect, it is inevitable that the necessary importance is given for post-graduate education in Turkey.

Postgraduate education has become an inevitable element in the educational policies and is cared much by developing and developed countries alike [10]. Alhas [11] pointed out to the importance of postgraduate education and mentioned that there was a considerable relation between efficient postgraduate education and the development level of a country. Similarly, Dilci [12] mentioned that one of the most important elements in scientific development of a country was the number of the people educated at postgraduate level.

The basic purpose of postgraduate education is to raise qualified human force that produces knowledge; uses it, criticizes and solves problems with a productive thinking style in institutes of universities in Turkey $[13,14]$. When sports is considered and investigated as a scientific branch, postgraduate education is also focused on in Sports Sciences. In Turkey, it is possible to say that postgraduate education in sports is generally provided in health sciences, social sciences and educational sciences institutes. However, Doctorate Education is mostly run by Health Sciences Institutes (SBE) under the title of Physical Education and Sports Department (BESABD). The distribution of the institutes and departments that provide postgraduate education at universities is visualized in Table 2 below [15].

Table 2. The Distribution of Sports Education Program Fields and Institutions at Postgraduate Level at Universities

\begin{tabular}{|c|c|c|c|}
\hline Department & Health Sciences Institutions & Social Sciences Institutions & Educational Sciences Institutions \\
\hline Training & 2 & & \\
\hline Physical Education Teachers & 1 & & \\
\hline Physical Education and Sports & 26 & & \\
\hline Physical Education and Sports Sciences & 1 & & \\
\hline Physical Education and Sports Education & 1 & & \\
\hline Exercise and Sportive Performance & 1 & & \\
\hline Movement and Training & 3 & & \\
\hline Psycho-Social Fields & 2 & & \\
\hline Recreation and Sports Management & 2 & & \\
\hline Sports Sciences & 2 & & \\
\hline Sports Sciences Technology & 1 & & \\
\hline Sports Health Sciences & 1 & & \\
\hline Sports Management & 1 & & \\
\hline Sports Management Sciences & 45 & & \\
\hline Total & & & \\
\hline
\end{tabular}


In Table 2, the postgraduate education departments and institutions in Sports Sciences are given. In this respect, it is clearly seen that postgraduate education is mostly provided in Physical Education and Sports Departments in Health Sciences Institutions.

The first doctorate study was conducted in Physical Education Sports in 1988 in Turkey [16]. Today, it is observed that the interest in doctorate education is increasing and the doctorate theses in this field are becoming widespread. Physical Education and Sports Department requires an integrated education, and aims to catch the scientific thinking dimension in doctorate programs [17]. Based on this purpose, it is known that the students graduating from Sports Sciences undergraduate field have an intense demand for postgraduate studies especially for doctorate studies. Çimen [18] stated that Physical Education Department undergraduate students considered postgraduate studies in a positive way, and emphasized that they were extremely enthusiastic for receiving postgraduate education.

Sports Management Doctorate Education is developing day by day at global scale, and is considered as a new discipline when compared with older disciplines like physics, mathematics, and literature. In addition, it is gaining acceleration with very different study fields in scientific terms [19, 20]. Sawyer [21] summarizes these different study fields as facilities, hotels, clubs, public and private institutions, non-profit organizations, adults, and handicapped individuals, etc. It is possible to say that Sports Management Doctorate programs are opened in Physical Education and Sports Departments at many universities in Turkey, which has not stayed indifferent to the global developments in Sports Management Doctorate programs; and the existing ones are improving themselves. Because, providing Sports Management Doctorate Education in a qualified manner in a country is an important step in raising qualified sports managers and scientists [22]. Based on the importance given to Sports Management Education, it is already known that the number of the doctorate studies and theses have increased in recent years. Together with this increase, the need for investigating and revealing the quality and quantity of these theses has aroused.

\subsection{The Aim of the Study}

Based on the abovementioned need, the aim of the present study is to investigate the methodological tendencies in the doctorate theses prepared in Turkish between the years 2007-2016 in Sports Management field based on the data received from the CHE National Thesis Center Database, which is open for public access. For this purpose, answers for the questions given in the following table have been sought in the context of the study.
Table 3. Research Questions

\begin{tabular}{|c|c|}
\hline \multirow{4}{*}{ DEMOGRAPHICAL } & $\begin{array}{l}\text { How is the distribution of the theses according } \\
\text { to years? }\end{array}$ \\
\hline & $\begin{array}{l}\text { How is the distribution of the theses according } \\
\text { to universities? }\end{array}$ \\
\hline & $\begin{array}{l}\text { How is the distribution of the theses according } \\
\text { to the title of the supervisors? }\end{array}$ \\
\hline & $\begin{array}{l}\text { How is the distribution of the theses according } \\
\text { to the genders of the people who prepare } \\
\text { them? }\end{array}$ \\
\hline \multirow{6}{*}{ METHOD } & $\begin{array}{l}\text { How is the distribution of the theses according } \\
\text { to research methods? }\end{array}$ \\
\hline & $\begin{array}{l}\text { How is the distribution of the theses according } \\
\text { to research design? }\end{array}$ \\
\hline & $\begin{array}{l}\text { How is the distribution of the theses according } \\
\text { to the sampling method? }\end{array}$ \\
\hline & $\begin{array}{l}\text { How is the distribution of the theses according } \\
\text { to the sampling groups? }\end{array}$ \\
\hline & $\begin{array}{l}\text { How is the distribution of the theses according } \\
\text { to the data collection tools? }\end{array}$ \\
\hline & $\begin{array}{l}\text { How is the distribution of the theses according } \\
\text { to the analysis methods? }\end{array}$ \\
\hline
\end{tabular}

\subsection{The Importance of the Study}

Sports Management Department emerged as one of the sub-disciplines of Management Sciences under the Physical Education and Sports High Schools (PESHS) in early 2000s, and has become a department that aims to train qualified sports managers and sports scientists with undergraduate and postgraduate education levels. In general, Sports Management Doctorate program is run under the Health Sciences Institutions, Physical Education and Sports Departments; and is becoming widespread with each passing day. In this respect, many doctorate theses are made in this field. It is possible to say that it has become necessary to investigate the methodological structures of these doctorate theses, which lose the quantity-quality balance sometimes. Because, doctorate theses, which are supposed to reflect the scientific quality of Sports Management, are extremely important for their present and future contributions to the field and to the literature. However, no studies have been detected in the literature investigating the methodological aspects of the Sports Management Doctorate Theses.

The methodological structure of the Sports Management Doctorate Theses being accurate or not in scientific terms might affect the whole of the thesis study. Therefore, assessing some of the existing theses in methodological terms may give us some clues on the scientific details of these theses. However, as it is mentioned above, it is seen that there are no such studies in the field of sports management. As a matter of fact, in the light of the findings that will be obtained in the scope of this study, it is aimed that the investigation of the methodological structures of the doctorate theses conducted in the last decade will cast a light on future studies. 
Sports Management may be considered as a discipline that is under the umbrella term of Social Sciences as for its contents. In this context, the methodology parts of the doctorate theses prepared in the field of Sports Management may be analyzed within a wide spectrum. Because, this is a field that is expected to face many different research methods, universe-sampling groups, and analysis methods. For this reason, the individuals preparing these theses being competent in the field of research methods and transferring this ability into practice are extremely important for the scientific quality of the doctorate thesis. If a thesis is prepared with missing points or with a mistaken methodology, this will affect the whole of it. In this respect, investigating the doctorate theses in terms of methodology and revealing the missing or erroneous parts will provide important clues for future researchers.

\subsection{The Limitations of the Study}

The study which was conducted to determine the quantity and quality of the theses conducted on Sports Management Doctorate Theses has been limited with the doctorate theses conducted between 2007-2016. For this purpose, the purpose of the study was to make an assessment on the methodological structures of the theses that were conducted in the last decade. In addition, in line with the purpose of the study, the data given in the methodology parts of the doctorate theses have been analyzed. Since the data on the methodology of a thesis must be given in the Methodology part of it, even data were provided in "Findings" part or in other parts of the theses, these were not assessed.

\section{Material \& Methods}

\subsection{The Study Model}

This study was conducted with the Qualitative Research Model, which is frequently used in social sciences, and the Case Study Design was also made use of. The data obtained in the course of the study were tested with the Content Analysis Method, and were interpreted.

The Qualitative Research Method allows us to understand and recognize the natural environment where a study is conducted, and explain the effects of these factors on the results. The researcher shows a holistic manner and follows a process "moving from the part towards the whole"[23, 24]. The Case Study Design, which is one of the Qualitative Research Methods, enables the researcher to investigate an up-to-date phenomenon in a multi-disciplinary, systematic and deep manner. One of the data collection tools of this design involves making use of existing documents $[25,26]$. The Content Analysis Method has been used in the present study, which involves the examination of the methodology parts of the existing theses on Sports Management. Content Analysis helps to assess the existing literature in a detailed manner, and meanwhile, it also allows the examination of the verbal, written and other materials in an objective and systematic manner [27, 28].

\subsection{The Universe-sampling}

The universe of the present study consists of the doctorate theses on Physical Education and Sports included in the CHE National Thesis Center Database. The Purposeful Sampling Method has also been used in the study to reach a sampling group that is adequate in size among the universe of the study. Purposeful Sampling Method allows investigating situations with rich data in detail [29]. In this context, the sampling of the study consisted of 111 Doctorate Theses conducted between 2007-2016 in Turkish included in the CHE National Thesis Center Database, which is open for public access.

\subsection{Data Collection Tool}

In this study, the "Sports Management Doctorate Theses Examination Form" was used. This form was created by the author of the study by re-organizing the "Distant Education Theses Examination Form", which was prepared by Gökmen et al. [30] in agreement with the purpose and content of the present study. The form included information on the definitive data, method, design, sampling method, sampling groups, data collection tools, and analysis methods of the Doctorate Theses.

\subsection{The Collection of the Data}

First of all, the BESABD search criteria were determined to define the Doctorate Theses, which are open for public access on the webpage of the CHE National Thesis Center Database, because Sports Management Doctorate Program is run under the BESABD title. However, Sports Management programs and Movement and Training Unit, Recreation and some Physical Education and Sports Teachers Doctorate programs are run under the dome of BESABD. For this reason, in case the BESABD criteria were applied without detailed scanning, Sports Management theses and Movement and Training Unit, Recreation and Physical Education and Sports Teachers Departments Doctorate Theses were also available on the website. For this reason, the scanning was made by entering the predefined search terms to the detailed search section to reach the Sports Management Doctorate Theses; and thus, the Sports Management Doctorate Theses were obtained. The search terms used for detailed search are visualized in the figure below. 


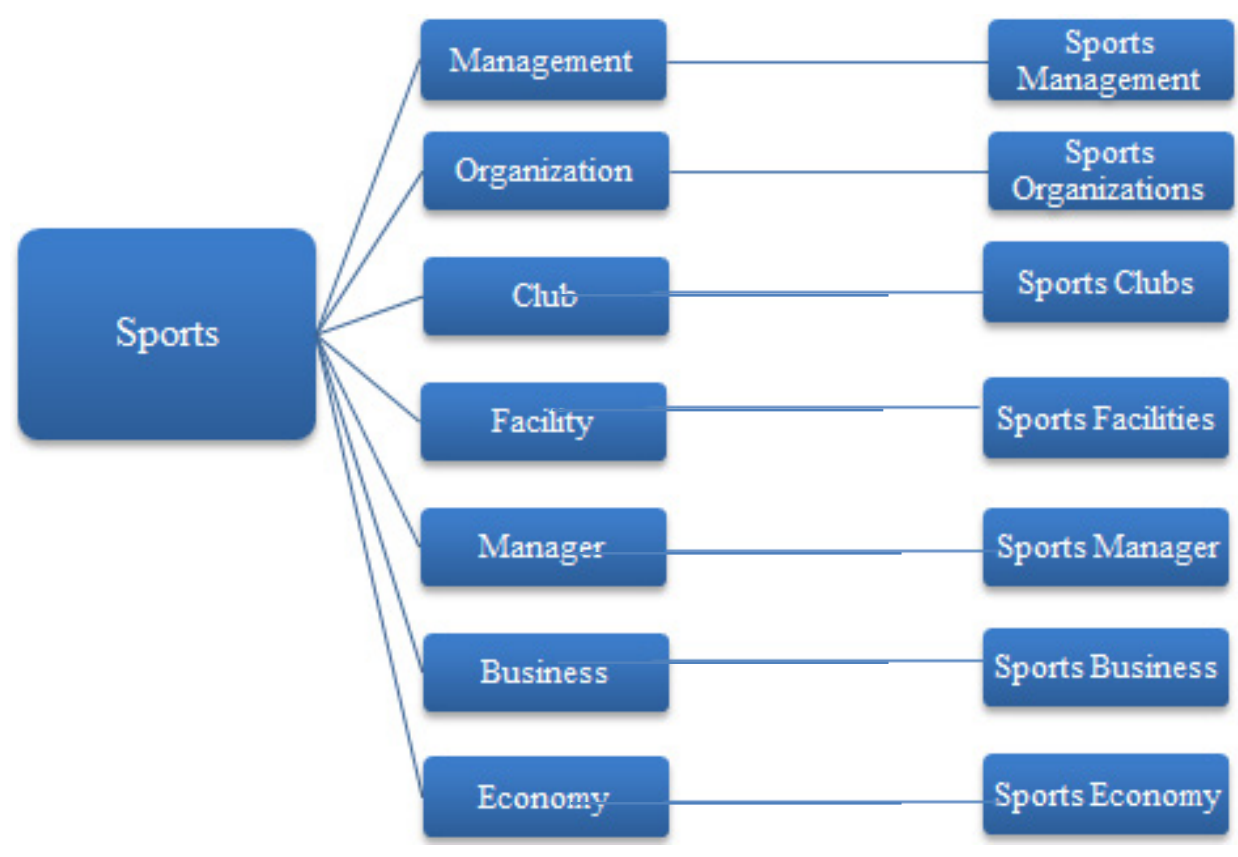

Figure 3. Research Terms Used for Detailed Scanning

The Sports Management Doctorate Theses that were reached as a result of the detailed search were downloaded in the PDF format, and were classified in the Excel Table in agreement with the Thesis Examination Form, and the data obtained were analyzed and were interpreted with the Content Analysis Method. It was aimed to proceed in an accurate manner in the course of the study, and the work-flow in data collection and analysis processes are visualized below:

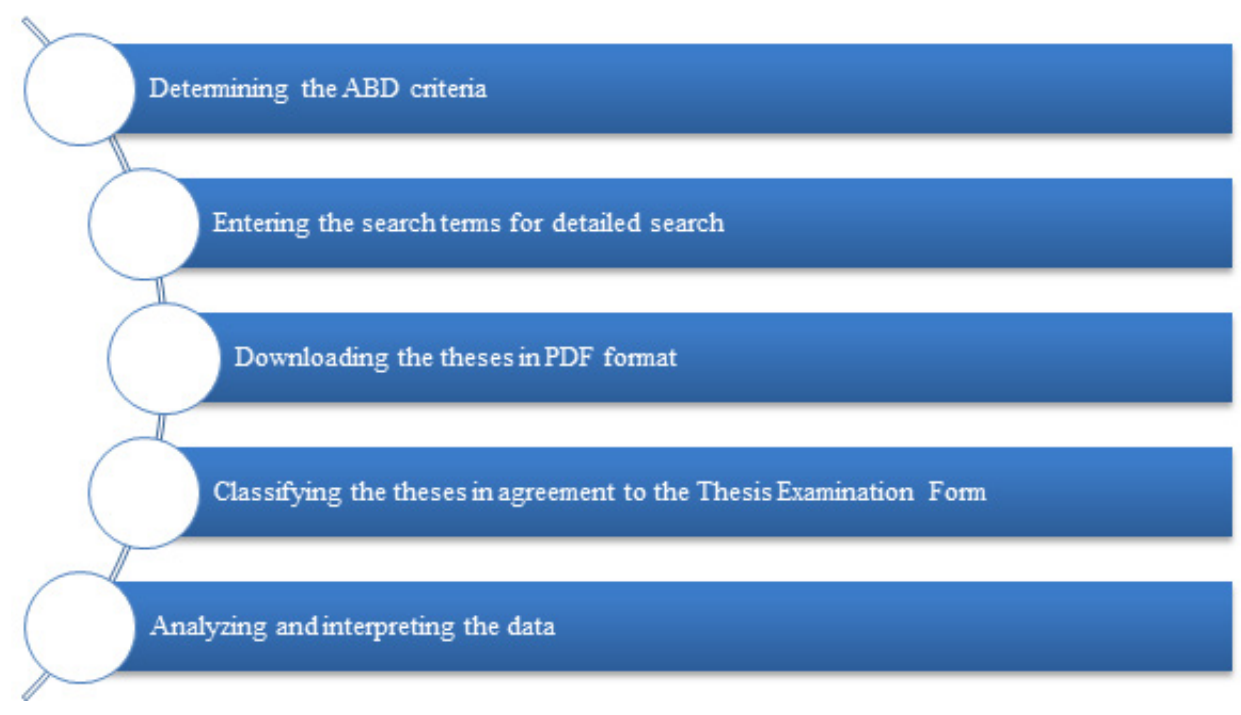

Figure 4. Data Collection Process and the Workflow

\subsection{The Analysis of the Data}

In analyzing the data that were classified according to the Sports Management Doctorate Theses Examination Form, each thesis was examined carefully, the demographical data on the identity of the theses (year, university, thesis Supervisor titles, the gender of the authors) were given, and the theses were then classified according to Research Methodology, Design, Sampling Method, Sampling Group, Data Collection Tool and
Analysis Methods. When doing this classification, the tables in the Office Excel 2017 program were used. The classified data were interpreted by making use of the SPSS 23.0 Program and Descriptive Statistics, Frequency and Percentage data.

\section{Findings}

In this part of the study, the findings obtained in the 
study are provided in two groups as Demographical and Methodological Assessments.

\subsection{Demographical Findings in the Sports Management Doctorate Theses}

Table 4. The Distribution of the Theses according to Years

\begin{tabular}{|c|c|c|}
\hline Year & F & \% \\
\hline 2007 & 9 & $\% 8.1$ \\
\hline 2008 & 8 & $\% 7.2$ \\
\hline 2009 & 12 & $\% 10.8$ \\
\hline 2010 & 7 & $\% 6.3$ \\
\hline 2011 & 24 & $\% 21.6$ \\
\hline 2012 & 14 & $\% 12.6$ \\
\hline 2013 & 17 & $\% 15.3$ \\
\hline 2014 & 8 & $\% 7.2$ \\
\hline 2015 & 7 & $\% 6.3$ \\
\hline 2016 & 5 & $\% 4.5$ \\
\hline
\end{tabular}

In Table 4, the distribution of the Doctorate Theses in Sports Management is given according to years. In this respect, the highest number of the theses was detected in 2011 " 24 " (21.6\%). Then, in 2013, $17(15.3 \%)$ theses were submitted; and in the third year (2012) the highest number of theses submitted was 14 (12.6\%). It is possible to claim that the number of the theses decreased in the last three years.

Table 5. The Distribution of the Theses According to Specific Areas in Sport Management

\begin{tabular}{|c|c|c|}
\hline $\begin{array}{c}\text { Spesific Areas in Sport } \\
\text { Management Theses }\end{array}$ & f & \% \\
\hline Management-Organization & 31 & $\% 27.9$ \\
\hline Sport Sociology & 29 & $\% 26.1$ \\
\hline Recreation & 17 & $\% 15.3$ \\
\hline Sport Economy & 12 & $\% 10.8$ \\
\hline Leadership in Sport & 9 & $\% 8.1$ \\
\hline Sport Law & 5 & $\% 4.5$ \\
\hline Sports Marketing & 5 & $\% 4.5$ \\
\hline Communication in Sport & 3 & $\% 2.7$ \\
\hline Total & 111 & $\% 100$ \\
\hline
\end{tabular}

In Table 5, the distribution of the doctorate theses in sports management is given according to spesific areas. It is seen that most theses in sports management are produced in the field of Management-Organization 31 (27.9\%). Management-Organization is followed by field of sport sociology with 29 theses $(26.1 \%)$, field of recreation with 17 theses (15.3\%), field of sport economy with 12 theses (10.8\%), field of leadership in sport with 9 theses $(8.1 \%)$, field of sport law with 5 theses $(4.5 \%)$, field of sports marketing with 5 theses $(4.5 \%)$ and field of communication in sport with 3 theses $(2.7 \%)$. Accordingly, it is seen that the specific study areas in sport management are mainly in fields of management-organization, sports sociology, recreation and sports economy.

Table 6. The Distribution of the Theses according to Universities

\begin{tabular}{|c|c|c|}
\hline University & f & \% \\
\hline Gazi & 57 & $\% 51.3$ \\
\hline Marmara & 23 & $\% 20.7$ \\
\hline Fırat & 11 & $\% 9.9$ \\
\hline Anadolu & 7 & $\% 4.5$ \\
\hline On Dokuz Mayıs & 5 & $\% 1.8$ \\
\hline Kocaeli & 2 & $\% 1.8$ \\
\hline Çukurova & 2 & $\% 0.9$ \\
\hline Dumlupınar & 1 & $\% 0.9$ \\
\hline Atatürk & 1 & $\% 0.9$ \\
\hline Ankara & 1 & $\%$ \\
\hline Kırıkkale & 1 & $\%$ \\
\hline
\end{tabular}

When Table 6 is analyzed it is clearly seen that the highest number of Doctorate Theses in Sports Management was submitted in Gazi University with $57(51.3 \%)$ theses. Gazi University is followed by Marmara with 23 theses (20.7\%), Firat with 11 theses $(9.9 \%)$, Anadolu with 7 theses (6.3\%), On Dokuz Mayis with 5 theses (4.5\%), Kocaeli and Çukurova with 2 theses (1.8\%), Dumlupınar, Atatürk, Ankara and Kırıkale Universities with 1 thesis $(0.9 \%)$. Since the whole of the theses included in the present study were submitted to Health Sciences Institutions, a separate table for Institutions was not formed.

Table 7. The Distribution of the Theses according to the Titles of the Supervisors

\begin{tabular}{|c|c|c|}
\hline Title & f & $\mathbf{\%}$ \\
\hline Prof. & 55 & $\% 49.5$ \\
\hline Assist. Prof. & 38 & $\% 34.2$ \\
\hline Assoc. Prof. & 15 & $\% 13.5$ \\
\hline Prof/Assist. Prof. & 2 & $\% 1.8$ \\
\hline Prof/Assoc. Prof. & 1 & $\% 0.9$ \\
\hline
\end{tabular}

In Table 7, the titles of the thesis Supervisors in Sports Management are given. In this respect, in 55 of the 111 Doctorate Theses $(49.5 \%)$ the title of the supervisor is Professor, in 38 of the theses (34.2\%) the title of the supervisor is Assistant Professor, in 15 of the theses $(13.5 \%)$ the title of the supervisor is Associate Professor, in 2 of the theses $(1.8 \%)$ the title of the supervisor is Professor/Associate Professor, and in 1 of the theses $(0.9 \%)$ the title of the supervisor is Professor and Associate Professor together. In the light of the present findings, it is clearly seen that half of the Doctorate Theses were supervised by professors. Another interesting point here is the fact that the number of the academicians that have the title of assistant professor is higher than those with 
associate professor titles.

Table 8. The Distribution of the Theses according to the Gender

\begin{tabular}{|c|c|c|}
\hline Gender & f & \% \\
\hline Male & 87 & $\% 78.3$ \\
\hline Female & 24 & $\% 21.6$ \\
\hline
\end{tabular}

In Table 8, the distribution of the Doctorate Theses that were prepared until the year of 2016 is given. When the distribution is considered according to gender, it is seen that 87 of the Doctorate Theses $(78.3 \%)$ were prepared by Males, 24 of them were prepared by (21.6\%) Females.

The Findings on the Methodologies of the Sports Management Doctorate Theses

Table 9. The Distribution of the Theses according to the Research Methodology

\begin{tabular}{|c|c|c|}
\hline Research Methodology & f & \% \\
\hline Qualitative & 10 & \%9 \\
\hline Quantitative & 7 & $\% 6.3$ \\
\hline Mixed & 2 & $\% 1.8$ \\
\hline Undefined & 92 & $\% 82.8$ \\
\hline
\end{tabular}

In Table 9, the research methodology used in the theses is given. In this respect, in 10 of the Doctorate Theses (9\%), the Qualitative Method was used; in $7(6.3 \%)$ the Quantitative Method; and in $2(1.8 \%)$ the Mixed Research Method was used. However, the most interesting finding on the research models is the fact that there is no information on which Research Methodology was used in $92(82.8 \%)$ of the 111 doctorate theses.

Table 10. The Distribution of the Theses according to the Research Design

\begin{tabular}{|c|c|c|}
\hline Research Design & f & \% \\
\hline Scanning & 65 & $\% 58.5$ \\
\hline Status & 3 & $\% 2.7$ \\
\hline Phenomenology & 3 & $\% 2.7$ \\
\hline Other & 5 & $\% 4.5$ \\
\hline Undefined & 36 & $\% 32.4$ \\
\hline
\end{tabular}

In Table 10, the research designs used in the theses on Sports Management are given. In this respect, in 65 of the Doctorate Theses $(58.5 \%)$ the Scanning Design was used; in 3 of the Doctorate Theses $(2.7 \%)$ the Phenomenology Design was used; again in 3 of the Doctorate Theses $(2.7 \%)$ the Status Design was used; in 5 of the Doctorate Theses (4.5\%) Other Research Designs were used. However, no information on Research Design was determined in 36 of the Doctorate Theses (32.4\%). Here, since more than one Research Design was used in some theses, the Total Research Design number has exceeded the total number of the theses.

When Table 11 is analyzed, it is clearly seen that mostly the Random Sampling Method was used in 20 theses (18\%). In addition to this, Accidental Sampling Method was used in 13 theses (11.7\%), Purposeful Sampling Method was used in 12 theses (10.8\%). In 6 of the theses (5.4\%), it was mentioned that the Whole of the Universe was reached. In 4 of the theses (3.6\%) Easy Sampling Method was used; in 3 of the theses, the Layered Sampling Method was used. In 7 of the theses $(6.3 \%)$ Other sampling methods were used. However, in 46 of the Doctorate Theses (41.4\%), no information was given on which Sampling Method was used.

Table 11. The Distribution of the Theses according to the Sampling Method.

\begin{tabular}{|c|c|c|}
\hline Sampling Method & f & \% \\
\hline Random & 20 & $\% 18$ \\
\hline Accidental & 13 & $\% 11.7$ \\
\hline Purposeful & 12 & $\% 10.8$ \\
\hline The Whole of the Universe & 6 & $\% 5.4$ \\
\hline Easy & 4 & $\% 3.6$ \\
\hline Layered & 3 & $\% 2.7$ \\
\hline Other & 7 & $\% 41.4$ \\
\hline Undefined & 46 & \\
\hline
\end{tabular}

Table 12. The Distribution of the Theses according to the Sampling Groups

\begin{tabular}{|c|c|c|}
\hline Sampling Groups & f & $\%$ \\
\hline Professional Footballer & 17 & $\% 15.3$ \\
\hline Adults & 16 & $\% 14.4$ \\
\hline Sportsmen & 15 & $\% 13.5$ \\
\hline Supporters & 10 & $\% 9$ \\
\hline University Students & 10 & $\% 9$ \\
\hline GHSIM Staff & 10 & $\% 9$ \\
\hline Academician & 9 & $\% 8.1$ \\
\hline Sports Manager & 9 & $\% 8.1$ \\
\hline Secondary School Students & 5 & $\% 4.5$ \\
\hline Referee & 3 & $\% 2.7$ \\
\hline Trainer & 3 & $\% 2.7$ \\
\hline $\begin{array}{l}\text { University Administrative } \\
\text { Staff }\end{array}$ & 3 & $\% 2.7$ \\
\hline Handicapped Sportsmen & 3 & $\% 2.7$ \\
\hline Other & 7 & $\% 6.3$ \\
\hline
\end{tabular}

In Table 12, the Sampling Groups in the theses are given. When the Sampling Groups in the Doctorate Theses are analyzed; it is seen that in $17(15.3 \%)$ of the theses, the Professional Footballers; in $16(14.4 \%)$ of the theses, Adults; in 15 (13.5\%) of the theses, Sportsmen; in 10 of the theses (9\%), the Supporters, University Students and Youth Services and Sports City Management Staff; in 9 of the theses, Academicians and Sports managers; in 5 of the theses, $(4.5 \%)$ Secondary School Students; in 3 of the theses (2.7\%) Referees, Trainers, University 
Administrative Staff and Handicapped Sportsmen were selected as the Sampling Group. In addition, in 7 (6.3\%) theses, Other Sampling Groups were included. Again, here, since more than one sampling group was used in some studies, the total sampling group is more than the total number of the theses.

Table 13. The Distribution of the Theses according to the Data Collection Tools

\begin{tabular}{|c|c|c|}
\hline Data Collection Tools & f & \% \\
\hline Questionnaire & 95 & $\% 85.5$ \\
\hline Interview & 9 & $\% 8.1$ \\
\hline Questionnaire/Interview & 5 & $\% 4.5$ \\
\hline Document & 2 & $\% 1.8$ \\
\hline
\end{tabular}

In Table 13, the Data Collection Tools used in the theses are given. In this respect, 95 of the theses $(85.5 \%)$ used the Questionnaire Method; 9 of the theses $(8.1 \%)$ used the Interview Method (with Semi-Structured Interview Form); 5 of the theses $(4.5 \%)$ used both Questionnaire and Interview method; 2 of the theses $(1.8 \%)$ used the existing local and foreign documents as Data Collection Tools.

Table 14. The Distribution of the Theses according to the Data Analysis Methods

\begin{tabular}{|c|c|c|}
\hline Data Analysis Methods & $\mathrm{f}$ & $\%$ \\
\hline Frequency & 77 & $\% 69.3$ \\
\hline Percentage & 77 & $\% 69.3$ \\
\hline Average & 30 & $\% 27$ \\
\hline Standard Deviation & 23 & $\% 20.7$ \\
\hline Reliability & 31 & $\% 27$ \\
\hline Factor & 24 & $\% 21.6$ \\
\hline T-Test & 52 & $\% 46.8$ \\
\hline Chi-Square & 22 & $\% 19.8$ \\
\hline Anova & 53 & $\% 47.7$ \\
\hline Correlation & 34 & $\% 30.6$ \\
\hline Regression & 10 & $\% 9$ \\
\hline Mann Whitney U & 21 & $\% 18.9$ \\
\hline Kruskall Wallis & 23 & $\% 20.7$ \\
\hline Descriptive Analysis & 4 & $\% 3.6$ \\
\hline YEM & 6 & $\% 5.4$ \\
\hline Content Analysis & 10 & $\% 9$ \\
\hline Path Analysis & 1 & $\% 0.9$ \\
\hline Data Enveloping & 1 & $\% 0.9$ \\
\hline Undefined & 1 & $\% 0.9$ \\
\hline
\end{tabular}

When Table 14 is analyzed, it is seen that the statistical analyses used in the sports method are given. Here, since more than one data analysis methods were used in some theses, the number of the total analysis method is more than the total number of the theses both in terms of Frequency and Percentage. In addition, the calculation of each Statistical Analysis was made separately as independent from each other. Again, the Data Analysis Methods are not classified according to the Quantitative Qualitative and Mixed Research Methodology, because the number of the theses in which the Research Methodology is not mentioned is 92. For this reason, it was not possible to classify the analysis methods according to the methodology. When Table X is analyzed, it is seen that the "Frequency" "Percentage" "Average" "Standard Deviation" "Anova" T-test" "Correlation" "Reliability" "Kruskall Wallis" Mann Whitney U" "Content Analysis" "Structural Equality Modeling" analysis methods were used respectively in the theses on Sports Management.

\section{Discussion}

In the present study, the aim was to examine the methodological tendencies in the Doctorate Theses written in Turkish on Sports Management that are open for public access in the CHE National Thesis Center Database between the years 2007-2016. Based on this purpose, the methods parts of the Doctorate Theses were examined. As a matter of fact, no studies were detected in which the doctorate theses were examined in methodological terms specifically in the field of Sports Management. For this reason, when the discussion part of the study was fictionalized, the studies in which the methodological tendencies were examined in the theses and scientific publications in Social Sciences and Educational Sciences and Health and Physical Sciences were taken as reference.

In this part, before making an assessment on the methodological structures of the theses, descriptive data were analyzed on the demographical properties of the Doctorate Theses.

\subsection{The Results on the Demographical Properties of the Sports Management Doctorate Theses, and Discussion}

In the present study, when the distribution of the doctorate thesis is analyzed according to the years, it was seen that most theses was submitted in 2011 with 24 theses (21.6\%). Then, in 2013, 17 theses (15.3\%) were submitted; and the third highest number of theses was in 2012 with 14 theses (12.6\%). In the last three years, there is a decrease in the number of the doctorate theses.

When the distribution of the doctorate theses is analyzed according to spesific study areas, it was seen that most theses in sports management are produced in the field of Management-Organization 31 (27.9\%).

Management-Organization is followed by field of sport sociology with 29 theses (26.1\%), field of recreation with 17 theses $(15.3 \%)$, field of sport economy with 12 theses $(10.8 \%)$, field of leadership in sport with 9 theses $(8.1 \%)$, field of sport law with 5 theses $(4.5 \%)$, field of sports marketing with 5 theses $(4.5 \%)$ and field of communication 
in sport with 3 theses $(2.7 \%)$. Accordingly, it is seen that the specific study areas in sport management are mainly in fields of management-organization, sports sociology, recreation and sports economy.

When the distribution of the universities is considered, it is seen that the highest number of the theses were submitted in Gazi University with 57 theses (51.3\%). Gazi University is followed by Marmara with 23 theses $(20.7 \%)$, Firat with 11 theses (9.9\%), Anadolu with 7 theses $(6.3 \%)$, On Dokuz Mayis with 5 theses (4.5\%), Kocaeli and Çukurova with 2 theses (1.8\%), Dumlupınar, Atatürk, Ankara and Kurkkale Universities with 1 thesis (0.9\%). Since the whole of the doctorate theses were prepared under the dome of Health Sciences Institutions, a separate table was not formed for Institutions. The reason of the highest number of theses being prepared in Gazi University may be the fact that the number of the academicians is adequate in Qualitative and Quantitative terms for Doctorate Education. In addition, it is also possible to claim that the specialization and academic variety in sports sciences field in this university are more than the other universities.

When the titles of the Supervisors of the theses in the study are analyzed it is clear that in 55 of the 111 theses (49.5\%) Professors, in 38 of the theses (34.2\%) Assistant Professors, in 15 of the theses (13.5\%) Associate Professors, in 2 of the theses (1.8\%) Professors/Assistant Professors and in 1 of the theses $(0.9 \%)$ Professors and Associate Professors were the supervisors. In the light of the findings of the study, it is seen that half of the theses were supervised by professors. The interesting point here is the fact that the number of the academicians with the title "Assist. Prof." is higher than those with "Assoc. Prof.". When the literature was investigated, unlike the results of the present study, the Supervisors were bearing the title Assist. Prof. with the highest number in studies conducted by Yaşar and Papatğa [31], Coşkun et al. [32], Kartopu [33]. When the genders of the doctorate candidates who prepared these doctorate theses are analyzed, it is seen that 87 of the theses (78.3\%) were prepared by Males, 24 of the theses $(21.6 \%)$ were prepared by Females. It is seen that the number of the male doctorate candidates is more than the number of the females. It is possible to say that the number of the female doctorate candidates must be increased in Sports Management. In this way, it may be possible for female individuals to have more places in academic life after they complete their doctorate studies.

\subsection{The Results on the Methodology of the Sports Management Doctorate Theses, and Discussion}

In the present study, when the research methods used in the Doctorate Theses were analyzed it is seen that in 92 of the 111 doctorate theses $(82.8 \%)$ no information was provided on which research method was used. On the other hand, in 10 of the theses (9\%) Qualitative Method; in 7 of the theses (6.3\%) Quantitative Method and in 2 of the theses (1.8\%) the Mixed Method was used. It is interesting that in the majority of the theses, there was no information on which method was used in them. As it is mentioned in the Limitations of the Study part, the other sections of the studies were not assessed even if information on the methodology was provided in these sections, and only the information given in the methods section was considered. In this respect, it is possible to claim that the research method not being defined in the majority of the doctorate theses conducted in the last decade in the field of Sports Management is a missing point in methodological terms, which caused that a general frame was not drawn for the research methods used in the theses. The methodological fiction is one of the most important factors that cast a light on the scientific value of a doctorate thesis. In this fiction, it is possible to make use of Qualitative, Quantitative or Mixed Research Methods according to the purpose of the study. While it is possible to handle the results in a full and multiple manner in studies that are conducted with Qualitative Research Method Creswell, [34]; more study groups may be reached in Quantitative Method, which facilitates measurements [35].

Mixed Research Method, on the other hand, enables the researchers to analyze and interpret the data obtained as a whole with the Qualitative and Quantitative Methods, and involves the mutual confirmation of the data [34]. Right at this point, it may be incorrect to make a judgment claiming that one Research Method is better than the other one.

Rather than such a comparison, it is necessary to define the must suitable method for the aim and content of the study, because the method used in a study is one of the most important elements of it; and defining it in an accurate manner will increase the quality of the study [36]. Of course, the most accurate method must be defined, and it must be clearly defined in the methodology section of the study.

In doctorate theses, and in other scientific studies, forming the methodological structure in an accurate manner will affect the whole of the study. For this reason, not defining the Research Method in Sports Management Doctorate Theses may cause that both the thesis and the competency of the individual preparing the thesis are questioned. Having competence in research methods, and exhibiting this competence in theory and practice may reinforce the scientific wealth of the Sports Management field, and cast a light on future theses. However, when the literature is reviewed, information is included on which research method is used in the theses and publications unlike the findings of the present study $[37,38,39,40,41$, $42,43,44,45]$. For the purpose of increasing the scientific value of the theses literature in Sports Management Doctorate field, the use of Mixed Method in these theses may be encouraged for the purpose of interpreting the data in multiple ways [46].

In the present study, when the research designs used in the theses are investigated, it is seen that in 65 of the theses 
(58.5\%) the Scanning Design; in 3 of the theses $(2.7 \%)$ the Phenomenology Design; again in 3 of the theses $(2.7 \%)$ the Status Design were used; and in 5 of them (4.5\%) Other designs were used. In using the Scanning Design in the theses, the fact that the aim was to determine the then-present status may be influential. The basic aim of the studies conducted with scanning design is to define the situation in question as it is $[47,38]$. For this reason, the event, object or individual in question is defined as is under the then-present conditions [48]. Although the Scanning Design was used frequently in the theses, the interesting point in this context is the fact that in $36(32.4 \%)$ of the doctorate theses, no information was given on the Research Design, which was also the case in Research Methods. When the studies in which the methodological tendencies were questioned were investigated in the literature, it is seen that the most frequently preferred research design was Scanning in many of the previously conducted studies by $[49,50,51,52,53,54]$.

However, although the results of the study show parallelism with the existing literature, the fact that there was no information provided on the methodology in 36 of the 111 doctorate theses may be interpreted as the methodological structure and design of the doctorate theses being weak. This status report may be interpreted as the sign of the methodological missing points in the Sports Management Doctorate Theses.

When the sampling methods used in the theses are investigated it is seen that the Random Sampling Method was used with the highest percentage in 20 theses (18\%). On the other hand, the number of the theses in which the Accidental Sampling Method was used was determined as $13(11.7 \%)$, the ones in which the Purposeful Sampling Method was used was 12 (10.8\%). In 6 of the theses (5.4\%) it was stated that the Whole of the Universe was reached. In 4 of the theses (3.6\%) the Easy Sampling Method, in 3 of the theses the Layered Sampling Method was made use of. In 7 of the theses $(6.3 \%)$ Other sampling methods were made use of. According to the existing literature in which the theses and scientific studies are investigated in different science fields, it is observed that similar results were reported with the present study, and the most frequently used sampling methods were Accidental, Random and Purposeful Sampling Methods [55, 56, 57, 58, 59].

Although similar results were determined with the literature, it is seen that there was no information on the methodology used in the 46 of the doctorate theses on Sports Management (41.4\%), which means almost half of the doctorate theses. Missing information on why the sampling method was used to form the sampling group in theses may prevent the accurate data being reached by the reader. It is possible to say that similar mistakes were made about the Research Method, Research Design and Sampling Method, and the quality of the methodological structures of the doctorate theses may be questioned in this respect.

When the sampling groups are investigated in the study, it was seen that in 17 of the theses (15.3\%), Professional Footballers; in 16 of the theses (14.4\%), Adults; in 15 of the theses (13.5\%), Sportsmen; in 10 of the theses (9\%), Supporters, University Students and Youth Services and Sports City Management (GHSIM) Staff; in 9 of the theses Academicians and Sports managers; in 5 of the theses (4.5\%), Secondary School Students; and in 3 of the theses (2.7\%) Referees, Trainers, University Administrative Staff and Handicapped Sportsmen were used as the Sampling Group. On the other hand, in 7 of the theses (6.3\%) Other Sampling Groups were included. It is seen that all the elements that constitute the "trivet" of the sports are included in the Doctorate Theses prepared in Sports Management field. On the other hand, it is possible to claim that the connection between sports and society is kept up-to-date by working with Adults, Handicapped Individuals and Public Staff.

In the study, when the Data Collection Tools used in the theses are analyzed it is clearly seen that in 95 of the theses $(85.5 \%)$, the Questionnaire Method; in 9 of the theses $(8.1 \%)$, the Interview Method (with Semi-Structured Interview Form); in 5 of the theses (4.5\%), both the Questionnaire Method and the Interview Method were used; and in 2 of the theses (1.8\%), the existing local and foreign documents were made use of as Data Collection Tools. In Sports Management, which is one of the study fields of Social Sciences, it is understood that Questionnaires are used as Data Collection Tool in the majority of the studies. It is possible to say that the results of the previously conducted studies in which methodological tendencies were investigated-interpreted and the results of the present study overlap with each other. As a matter of fact, it is clearly understood from the data that the most frequently used Data Collection Tool in the literature is Questionnaire Method $[60,61,62,63,64,65$, $66,67,68]$.

It is possible to think that questionnaires serve the purpose of studies as Data Collection Tools, and facilitate the work of the authors. Baş [69] reported that questionnaires facilitated the work of the researchers in reducing the cost in reaching the target audience and in terms of the effort and time spent on the study activities.

When the data analysis methods used in the theses are analyzed in the present study it is seen that the Frequency, Percentage, Standard Deviation and Average values of Descriptive Analyses were used; and the T-test, Correlation, Chi-Square and ANOVA tests, which are among the predictive analyses, were also made use of. In addition to these basic analyses, it is also understood that Content Analysis, Structural Equality Modeling and similar analyses were also made use of. It is seen in the literature that similar results were reported in the Content Analysis studies conducted in the field of Educational Sciences; and the Frequency, Percentage, Standard Deviation, Average, ANOVA, Correlation and T-Test are used frequently $[70,71,72,73,74,75,76]$. 
It is possible to claim that the basic analysis methods are used in Sports Management Doctorate Theses, and mostly the binary and multiple comparison studies are made. However, in the theses that are run with mainly Scanning Design, the Structural Equality Modeling, MANOVA, Regression and similar advanced statistical methods are not preferred more [30]. Using advanced analysis methods will provide clues on the depth or the contents and scientific importance of the studies. In this respect, it is possible to claim that the analysis methods used in the theses in Sports Management are relatively narrow and unproductive; and the analysis methods repeat each other around the same axis. Since it is possible to reach more explanatory, comprehensive and detailed results with different and advanced analysis methods, using such advanced analysis methods in future doctorate theses may bring benefits.

\section{Results and Recommendations}

In the context of the study, the methodological tendencies of the Doctorate Theses written in Turkish and conducted between 2007-2016 were investigated. In this respect; out of the 111 Doctorate Theses;

- 92 did not state which Research Method was used,

- 36 did not state which Research Design was used,

- 46 did not state which Sampling Method was used.
- In the majority of the Doctorate Theses that were investigated in the context of the present study, it was determined that Questionnaires were used as Data Collection Tools, and the most-frequently used Data Analysis Methods were the Frequency, Percentage, Average, Standard Deviation, and the Predictive T-Test, ANOVA, Chi-Square, Correlation Methods.

- It was determined that the Professional Footballers, Sportsmen, Referees, Trainers, Supporters, GHSIM Staff and Physical Education and Sports High School (PESHS) Academicians and Handicapped Sportsmen, Adults and Public Officials were used as Sampling Groups in the Doctorate Theses.

- It was also determined that the majority of the Doctorate Theses that were analyzed in the context of the study were prepared in Gazi University under the Supervision of Professors and Assistant Professors; and 87 of the 111 theses were prepared by males, and 24 were prepared by females. In addition, the majority of the theses were prepared in 2011 with 24 theses; and in recent years, the number of the theses has reduced.

According to the results of the study, the problems on the methodological structures of the theses and the offers for solution are visualized in the table below.

Table 15. Findings and Recommendations

\begin{tabular}{|c|c|}
\hline Findings & Recommendations \\
\hline $\begin{array}{l}\text { In the } 111 \text { Doctorate Theses; } \\
\text { - } 92 \text { did not state which Research Method was } \\
\text { used, } \\
\text { - } 36 \text { did not state which Research Design was } \\
\text { used, } \\
\text { - } 46 \text { did not state which Sampling Method was } \\
\text { used. }\end{array}$ & $\begin{array}{l}\text { - It may be targeted that the doctorate candidates increase their information on } \\
\text { Scientific Research Techniques (SRT) during their Doctorate Education processes. } \\
\text { For this, the SRT classes must be made common during Doctorate Education process, } \\
\text { the contents of these classes must be enhanced, and practice works must be made on } \\
\text { the topics of these classes, which may provide that the methodological missing points } \\
\text { may be eliminated and the methodological structures of the theses are strengthened. }\end{array}$ \\
\hline $\begin{array}{l}\text { - In the majority of the Doctorate Theses, } \\
\text { Frequency, Percentage; T-test, ANOVA and } \\
\text { similar limited and self-repeating analysis } \\
\text { methods were used. }\end{array}$ & $\begin{array}{l}\text { - Advanced Level Analysis Methods (Structural Equality Modeling, MANOVA, } \\
\text { Regression, Path Analysis) and especially Mixed (Quantitative+Qualitative) } \\
\text { Research Methods may be used to reach more comprehensive, explanatory, and } \\
\text { striking scientific results. } \\
\text { Based on this aim, doctorate candidates may be provided with advanced analysis } \\
\text { methods during their Doctorate Education processes; and the Thesis Supervisors may } \\
\text { encourage the candidates to conduct the theses with Mixed Method. } \\
\text { - The Doctorate Educational Curriculum may be re-designed in the light of the SRT } \\
\text { classes, the contents of the classes may be designed to increase the scientific and } \\
\text { methodological effects and contributions, and the scientific research skills of the } \\
\text { doctorate candidates may be increased before the theses stage. }\end{array}$ \\
\hline
\end{tabular}

It is seen that in the majority of the doctorate theses on sports management, there is no information on the Research Method, Research Design and Sampling Method. It must be considered that the missing, erroneous or mistaken fictionalizing of doctorate theses, which are considered as having high scientific value, in methodological terms will affect the whole of the theses in a negative way. Besides, when the results are compared with the results reported in the literature, it is possible to say that the Sports Management Doctorate Theses have missing points at high levels and are inadequate in terms of Methodology, Research Design and Sampling Method. In addition, it is also clear that the methodological structures of the theses are extremely ambiguous and weak; and cannot convey the methodological data to the reader in an accurate manner. Right at this point, it is necessary that the Sports Management Doctorate These literature is considered again, and future theses are investigated and analyzed in a meticulous manner especially in the writing stage of the theses. 


\section{REFERENCES}

[1] H. Sunay. Spor Yönetimi, Ankara, Gazi Kitabevi, 2016.

[2] A. Yetim, Ö. Şenel. Türkiye'de spor yöneticisi yetiştirme faaliyetlerinin görünümü, Milli Eğitim Dergisi, No. 250, $28-40,2001$.

[3] S. Erden, A. Akça, F. Korkmaz, R. Ediz. Uludağ Üniversitesi eğitim fakültesi beden eğitimi ve spor bölümü özel yetenek birinci aşama sınavını kazanan öğrencilere uygulanan testler arasındaki ilişki, Eğitim Fakültesi Dergisi, Vol. 18, No. 1, 83-92, 2005.

[4] Y.E. Karakaya, B. Çoban. ARHESIS tematik ağ projesi kapsamında spor eğitimi alanların Türkiye'de spor eğitimi kurumlarına uyumu, Turkish Studies, Vol. 9, No. 5, 1229-1249, 2014.

[5] CHE, Center of Statistics. (2017). Online Available: https://istatistik.yok.gov.tr.

[6] P.M. Pedersen, L. Thibault. Contemporary Sport Management, Champaign, Human Kinetics, 2014.

[7] L. Chalip. Toward a distinctive sport management discipline, Journal of Sport Management, Vol. 20, No. 1, 1-21, 2006.

[8] R. Hoyer, C.T. Avron, M. Nicholson, Stewart B. Sport Management Principles and Applications, London, Routledge, 2015.

[9] A. Yiamouyiannis, G.G. Bower, J. Williams, D. Gentile, H. Alderman. Sport management education: Accreditation, accountability, and direct learning outcome assessments, Sport Management Education Journal, Vol. 7, No. 1, 51-59, 2013.

[10] S. İzgi. Sosyal bilgiler öğretmenliği öğrencilerinin lisansüstü eğitime ilişkin tutumlarının bazı değişkenler açısından incelenmesi. Yayınlanmamış Yüksek Lisans Tezi, İnönü Üniversitesi, Malatya, 2016.

[11] A. Alhas. (2006). Lisansüstü eğitim yapmakta olan Milli Eğitim Bakanlığı öğretmenlerinin lisansüstü eğitime bakış açıları (Ankara ili örneği). Yayınlanmamış Yüksek Lisans Tezi, Gazi Üniversitesi, Ankara, 2016.

[12] T. Dilci. Eğitim bilimleri alanında yürütülen lisansüstü eğitimin öğrenci ve öğretim elemanları görüşlerine dayalı olarak değerlendirilmesi. Yayınlanmamış Doktora Tezi, Frrat Üniversitesi, Elazığ, 2009.

[13] S. Karaman, F. Bakırcı. Türkiye'de lisansüstü eğitim: Sorunlar ve çözüm önerileri, Sosyal Bilimler Araştırmaları Dergisi, No. 2, 94-114, 2010.

[14] M. Bozan. Lisansüstü eğitimde nitelik arayışları, Sosyal ve Beşeri Bilimler Dergisi, Vol. 4, No. 2, 177-187, 2012.

[15] Y.E. Karakaya, M. Tel. Küreselleşme çă̆1 ve yükseköğretimde spor bilimleri üzerine, Turkish Studies, Vol. 9, No. 11, 321-331, 2015.

[16] C. Açıkada. Türkiye'de spor eğitimi veren kurumların yeniden yapılanması ve hakemli çalışmaların gelişimi, Hacettepe Spor Bilimleri Dergisi, Vol.8, N0. 1, 17-31, 1997.

[17] Gedik University. (2017). Online Available: http://www.gedik.edu.tr/akademik-birimler/enstituler/saglik -bilimleri-enstitusu/doktora-programi/beden-egitimi-ve-spo r-bilimleri

[18] A. Çimen. Beden eğitimi ve spor öğretmeni adaylarının lisansüstü eğitime ilişkin görüşleri ve beklentilerinin incelenmesi. Yayınlanmamış Yüksek Lisans Tezi, Fırat Üniversitesi, Elazı̆̆ 2015.

[19] F. Zhang, J. Wang, S.D. Min, K.K. Chen, H. Huang. Influence curriculum quality and educational service quality on student experiences: A case study in sport management programs, Journal of Hospitality Leisure Sport and Tourism, No.18, 81-91, 2016.

[20] B.R. Humpreys, J. Maxcy. The role of sport economics in the sport management curriculum, Sport Management Review, No.10, 177-189, 2007.

[21] T.H. Sawyer. Sport management: Where should it be housed? Journal of Physical Education, Recreation \& Dance, Vol.64, No.9, 4-7, 1993.

[22] F. Skinner, K. Gilbert. Sport management education: Teaching and learning for the future, Sport Management Review, No.10, 125-131, 2007.

[23] N. Iş̧koğlu. Eğitimde nitel araştırma, Eğitim Araştırmaları Dergisi, Vol.20, No.3, 1-17, 2005.

[24] E. Karadăg. Eğitim bilimleri doktora tezlerinde kullanılan araştırma modelleri: Nitelik düzeyleri ve analitik hata tipleri, Kuram ve Uygulamada Eğitim Yönetimi, Vol.16, No.1, 49-71, 2010.

[25] A. Yıldırım, H. Şimşek. Sosyal Bilimlerde Nitel Araştırma Yöntemleri, Seçkin Yayıncılık, Ankara, 2016.

[26] C. Robson. Real Word Research, Blackwell, Oxford Press, 2001.

[27] R.T. Falkingham, R. Reeves. Context analysis: A technique for analyzing research in a field, applied to literature on the management of R\&D et the section level, Scientometrics, Vol.4, No.2, 97-121, 1998.

[28] E. Tavşancıl, E. Aslan. İçerik Analizi ve Uygulama Örnekleri, Epsilon Yayınları, İstanbul, 2001.

[29] S. Sidekli. Eylem araştırması: İlköğretim 4. Sınıf öğrencilerinin okuma ve anlama güçlüklerinin giderilmesi, Türklük Bilimi Araştırmaları, No.27, 563-580, 2010.

[30] Ö.F. Gökmen, M. Uysal, H. Yaşar, A. Kırksekiz, G.M. Güvendi, M.B. Horzum. Türkiye'de 2005-2014 yılları arasında yayınlanan uzaktan eğitim tezlerindeki yöntemsel eğilimler: Bir içerik analizi, Eğitim ve Bilim Dergisi, Vol.42, No.189, 1-25, 2017.

[31] Ş. Yaşar, E. Papatğa. İlkokul matematik derslerine yönelik yapılan lisansüstü tezlerin incelenmesi, Trakya Üniversitesi Eğitim Fakültesi Dergisi, Vol.5, No.2, 113-124, 2015.

[32] İ. Coşkun, Ş. Dündar, C. Parlak. Türkiye'de özel eğitim alanında yapılmış lisansüstü tezlerin çeşitli değişkenler açısından incelenmesi (2008-2013), Ege Eğitim Dergisi, Vol.15, No.2, 375-396, 2014.

[33] S. Kartopu. Türkiye'de görsel sanatlar alanında yapılan lisansüstü tez çalışmalarının betimsel incelemesi, Sınırsız 
Eğitim ve Araştırma Dergisi, Vol.1, No.1, 81-98, 2016.

[34] J.W. Creswell. Research Design: Qualitative, Quantative and Mixed Methods Approaches, Sage Publ, California, 2014.

[35] D. Y1ldı. Uluslararası dil dergilerinde yayımlanan makalelerin amaç/konu ve yöntem açısından incelenmesi, Gazi Eğitim Fakültesi Dergisi, Vol.36, No.2, 399-425, 2016.

[36] R.S. Arık, M. Türkmen. Eğitim Bilimleri Alanında Yayımlanan Bilimsel Dergilerde Yer Alan Makalelerin İncelenmesi, I. Uluslararası Türkiye Eğitim Araştırmaları Kongresi, Çanakkale, Turkey, 26-35, 2009.

[37] C.H. Dikmen, V. Demirer. Türkiye'de teknolojik pedagojik alan bilgisi üzerine 2009-2013 yılları arasında yapılan çalışmalardaki eğilimler, Turkish Journal of Education, Vol.5, No.1, 33-47, 2016.

[38] M. Erdoğan, Ç.G. Kayır, H. Kaplan, Ü.Ö. Aşık Ünal, Ş. Akbunar. 2005 yılı ve sonrasında geliştirilen öğretim programları ile ilgili öğretmen görüşleri: 2005-2011 yılları arasında yapılan araştırmaların içerik analizi, Kastamonu Eğitim Dergisi, Vol.23, No.1, 171-196, 2015.

[39] E. Evrekli, D. İnel, H. Deniş, H. A.G. Balım, Methodological and statistical Problems in Graduate Theses in the Field of Science Education, Elementary Education Online, Vol.10, No.1, 206-218, 2011.

[40] B. Ulutaş, S. Üner, N. Turan Oluk, A. Yalçın Çelik, H. Akkuş. Türkiye'de kimya eğitimi makalelerinin incelenmesi: 2000-2013, Kırşehir Eğitim Fakültesi Dergisi, Vol.16, No.2, 141-160, 2015.

[41] E.Ç. Altuntaş, S.L. Turan. Çevre eğitiminde 2010-2015 yılları arasında yapılan araştırmalar ve eğilimler, Eğitim ve Toplum Araştırmaları Dergisi, Vol.3, No.2, 1-14, 2016.

[42] Z. Çubukçu, B.Y. Yılmaz, T. İnci. Karşılaştırmalı eğitim programları araştırma eğilimlerinin belirlenmesi-bir içerik analizi, Uluslararası Türkçe Edebiyat Kültür Eğitim Dergisi, No.5, 446-468, 2016

[43] A.A. Kurt, D. Orhan, F. Yaman, M.Ș. Solak, F. Türkan. Bilgi ve iletişim teknolojileri ışığında Türkiye'de yapılan okuryazarlık çalışmalarımdaki eğilim, Eğitim Teknolojileri Araştırmaları Dergisi, 5(2), 1-21, 2014.

[44] M. Fırat, BIT odaklı genç akademisyenlerin bilimsel araştırma yöntem paradigmalarının incelenmesi. III. Uluslararas1 Eğitimde Yeni Yönelimler Konferans1, İzmir, Türkiye, 16-24, 2016.

[45] M.B. Horzum, M. Özkaya, M. Demirci, M. Alpaslan. Review of Turkish distance education research, Inonu University Journal of The Faculty of Education, Vol.14, No.2, 79-100, 2013.

[46] F. Ulutaş, B. Ubuz, Matematik eğitiminde araştırmalar ve eğilimler, Elementary Education Online, Vol.7, No.3, 614-626, 2008.

[47] A. Şimşek, N. Özdamar, Ö. Uysal, K. Kobak, C. Berk, T. Kılıçer, H. Çiğdem. İki binli yıllarda Türkiye'deki eğitim teknolojileri araștırmalarında gözlenen eğilimler, Kuram ve Uygulamada Eğitim Bilimleri, Vol.9, No.2, 941-966, 2009.

[48] L. Cohen, L. Manion, K. Morrison. Research Methods in Education, Routledge, Oxon, 2007.
[49] M. Kurtoğlu, S.S. Seferoğlu. Öğretmenlerin teknoloji kullanım ile ilgili Türkçe kaynaklı dergilerde yayımlanmış makalelerin incelenmesi, Journal of Instructional Technologies \& Teacher Education, Vol.2, No.3, 1-10, 2013.

[50] N. Ataseven, A. Oğuz. Türkiye'de öğrenme stilleri konusunda yapılan tezlerin incelenmesi, Eğitim ve Öğretim Araştırmaları Dergisi, Vol.4, No.3, 192-205, 2015.

[51] İ. Seçer, İ. Ay, C. Ozan, B.Y. Y1lmaz. Research trends in the field of guidance and psychological counseling: A content analysis, Turkish Psychological Counseling and Guidance Journal, Vol.5, No.4), 49-60, 2014.

[52] D.A. Üstündağ. Türkiye'de bilgisayar ve öğretim teknolojileri eğitimi alanındaki yüksek lisans tezlerinin araștırma eğilimleri, Eğitim Teknolojisi Kuram ve Uygulama, Vol.3, No.1, 55-73, 2013.

[53] O. Fazlığulları, N. Kurul, Türkiye'deki eğitim bilimleri doktora tezlerinin özellikleri, Mehmet Akif Üniversitesi Eğitim Fakültesi Dergisi, Vol.1, No.24, 43-75, 2012.

[54] D. Şahin, Ş. Calp, P. Bulut, Y. Kuşdemir. Investigation of the graduate theses in the department of primary teacher education in terms of various criteria, Journal of World of Turks, Vol.5, No.3, 187-202, 2013.

[55] B. Varışoğlu, A. Şahin, Y. Göktaş. Türkçe eğitimi araştırmalarında eğilimler, Kuram ve Uygulamada Eğitim Bilimleri, Vol.13, No.3, 1767-1781, 2013.

[56] S. Yüksel, K. Gündoğdu, B. Akyol, R.K. Vural. Hayat boyu ögrenme konusunda yayımlanan tez ve makalelere ilişkin bir içerik analizi: 2000-2015, Erzincan Üniversitesi Eğitim Fakültesi Dergisi, Vol.18, No.2, 1491-1505, 2016.

[57] A. Babur, A. Kiper, B. Çukurbaşı, Ö.A. Özer, İ. Tonbuloğlu, S. Küçük, E. Demirhan, Ö.C. Güngören, M. Kıyıcı, M.B. Horzum. 2009-2013 yılları arasında uzaktan eğitim dergilerinde yayınlanan makalelerin yöntemsel açıdan incelenmesi, Sakarya University Journal of Education, Vol.6, No.1, 123-140, 2016.

[58] Z. Selçuk, M. Palanc1, M. Kandemir, \& H. Dündar. Eğitim ve bilim dergisinde yayınlanan araştırmaların eğilimleri: İçerik analizi, Eğitim ve Bilim Dergisi, Vol.39, No.173, 430-451, 2014.

[59] N. Biçer. Yabancılara Türkçe öğretimi alanında yayınlanan makaleler üzerine bir analiz çalışması, Pamukkale Üniversitesi Sosyal Bilimler Enstitüsü Dergisi, No, 27, 236-247, 2017.

[60] Y. Gülbahar, A. Alper. Content analysis of the studies in instructional Technologies area, Ankara University Journal of Faculty of Educational Sciences, Vol.42, No,2, 93-111, 2009.

[61] A. Simşek, N. Özdamar, G. Becit, K. Kılıçer, Y. Akbulut, Y. Yıldırım. Türkiye'deki eğitim teknolojileri araştırmalarında güncel eğilimler, Selçuk Üniversitesi Sosyal Bilimler Enstitüsü Dergisi, No.19, 439-458, 2008.

[62] Y. Göktaş, S. Küçük, M. Aydemir, E. Telli, Ö. Arpacık, G. Yıldırım, İ. Reisoğlu. Türkiye'de eğitim teknolojileri araştırmalarında eğilimler: 2000-2009 dönemi makalelerin içerik analizi, Kuram ve Uygulamada Eğitim Bilimleri, Vol.12, No.1, 177-199, 2012. 
[63] M. Ergun, F. Çilingir. İlköğretim Bölümünde Yapılan Lisansüstü Tezlerin İncelenmesi: On Dokuz Mayıs Üniversitesi Örneği. VI. Ulusal Lisansüstü Eğitim Sempozyumu Sakarya, Türkiye, 84-90, 2013.

[64] H.D. Kayaoğlu. İstanbul Üniversitesi bilgi ve belge yönetimi bölümünde araştırma eğilimleri 1967-2008: Lisansüstü tezlerinin içerik analizi, Türk Kütüphaneciliği Dergisi, Vol.23, No.3, 535-562, 2009.

[65] M. Doğru, T. Gençosman, A.N. Atalkın, F. Şeker. Fen bilimleri eğitiminde çalışılan yüksek lisans ve doktora tezlerinin analizi, Türk Fen Eğitimi Dergisi, Vol.9, No.1, 49-64, 2012.

[66] N. Çelik. Yenilikçilik konusunda yapılan doktora tezlerinin içerik analizi yöntemiyle değerlendirilmesi, Uluslararası Ekonomi ve Yenilik Dergisi, Vol.2, No.1, 29-42, 2016.

[67] G. Sert, M. Kurtoğlu, A. Akıncı, S.S. Seferoğlu. Öğretmenlerin teknoloji kullanma durumlarını inceleyen araştırmalara bir bakış: Bir içerik analizi, Akademik Bilişim Dergisi, N0.1, 1-8, 2012.

[68] B. Ahi, A.O. Kıldan. Türkiye'de okul öncesi eğitimi alanında yapılan lisansüstü tezlerin incelenmesi (2022-2011), Mehmet Akif Ersoy Üniversitesi Eğitim Fakültesi Dergisi, Vol.13, No.27, 23-46, 2013.

[69] T. Baş, Anket Nasıl Hazırlanır, Uygulanır, Değerlendirilir? Seçkin Yayıncılık, Ankara, 2005.

[70] E.Y. Şahin, F. Kana, B. Varışoğlu. Türkçe eğitimi bölümlerinde yapılan lisansüstü tezlerin araștırma eğimleri, International Journal of Human Science, Vol.10, No.2, 356-378, 2013.

[71] S. Akaydın, M.A. Cecen. Okuma becerisiyle ilgili makaleler üzerine bir içerik analizi, Eğitim ve Bilim Dergisi, Vol.40, No.178, 183-198, 2015.

[72] S. Öngöz, S.. Aydın, D.A. Aksoy. Türkiye'de eğitim bilimleri alanında yapılan çoklu ottam konulu lisansüstü tezlerin eğilimleri, Journal of Instructional Technologies \& Teacher Education, Vol.5, No.1, 45-58, 2016.

[73] M. Bektaş, H. Dündar, A. Ceylan. Ulusal sınıf öğretmenliği eğitimi sempozyumu bildirilerinin çeşitli değişkenler açısından incelenmesi, Uşak Üniversitesi Sosyal Bilimler Dergisi, Vol.6, No.2, 197-222, 2013.

[74] C. Ozan, E. Köse. Eğitim programları ve eğitim alanındaki araştırma eğilimleri, Sakarya University Journal of Education, Vol.4, No.1, 116-136, 2014.

[75] E.K. Çakmak, G. Özüdoğru, Ș.B. Bozkurt, Ü. Ülker, N.Ö. Ünsal, K. Boz, Ö.F. Bozkurt, E.E. Sönmez, C.B. Kaya, C. Karaca, H. Bahadır, H.Ü. Gül. 2014 yılında eğitim teknolojileri alanındaki yayımlanan makalelerin incelenmesi, Eğitim Teknolojisi Kuram ve Uygulama, Vol.6, No.1, 80-108, 2016.

[76] S.N. Sarı. Türkiye'de Kimya Eğitimi Alanında 2000-2010 Yılları Arasında Yazılmış Yüksek Lisans Tezlerinin İçerik Analizi. Yayınlanmamıs Yüksek lisans tezi, Gazi Üniversitesi, Ankara, 2011. 